\title{
Communicating amidst reality: Ezekiel's communication as a response to his reality
}

\begin{tabular}{|c|c|}
\hline \multicolumn{2}{|c|}{$\begin{array}{l}\text { Authors: } \\
\text { Johan Serfontein }{ }^{1} \\
\text { Wilhelm J. Wessels }{ }^{1}\end{array}$} \\
\hline \multicolumn{2}{|c|}{$\begin{array}{l}\text { Affiliations: } \\
{ }^{1} \text { Department of Biblical and } \\
\text { Ancient Studies, University of } \\
\text { South Africa, South Africa }\end{array}$} \\
\hline \multicolumn{2}{|c|}{$\begin{array}{l}\text { Correspondence to: } \\
\text { Wilhelm Wessels }\end{array}$} \\
\hline \multicolumn{2}{|c|}{$\begin{array}{l}\text { Email: } \\
\text { wessewj@telkomsa.net }\end{array}$} \\
\hline \multicolumn{2}{|c|}{$\begin{array}{l}\text { Postal address: } \\
\text { PO Box 392, University of } \\
\text { South Africa 0003, } \\
\text { South Africa }\end{array}$} \\
\hline \multicolumn{2}{|c|}{$\begin{array}{l}\text { Dates: } \\
\text { Received: } 17 \text { Feb. } 2014 \\
\text { Accepted: } 14 \text { Mar. } 2014 \\
\text { Published: } 13 \text { Aug. } 2014\end{array}$} \\
\hline \multicolumn{2}{|c|}{$\begin{array}{l}\text { How to cite this article: } \\
\text { Serfontein, J. \& Wessels, } \\
\text { W.J., 2014, 'Communicating } \\
\text { amidst reality: Ezekiel's } \\
\text { communication as a response } \\
\text { to his reality', Verbum et } \\
\text { Ecclesia } 35(1) \text {, Art. \#1335, } \\
8 \text { pages. http://dx.doi. } \\
\text { org/10.4102/ve.v35i1.1335 }\end{array}$} \\
\hline \multicolumn{2}{|c|}{$\begin{array}{l}\text { Note: } \\
\text { Johan Serfontein recently } \\
\text { completed his doctor's } \\
\text { degree with the Departme } \\
\text { of Biblical and Ancient } \\
\text { Studies at University of } \\
\text { South Africa in } 2012 \text {. }\end{array}$} \\
\hline \multicolumn{2}{|c|}{$\begin{array}{l}\text { Copyright: } \\
\text { (C) 2014. The Authors. } \\
\text { Licensee: AOSIS } \\
\text { OpenJournals. This w } \\
\text { is licensed under the } \\
\text { Creative Commons } \\
\text { Attribution License. }\end{array}$} \\
\hline \multicolumn{2}{|l|}{ Read online: } \\
\hline 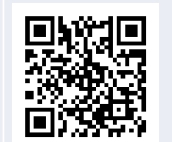 & $\begin{array}{l}\text { Scan this QR } \\
\text { code with your } \\
\text { smart phone or } \\
\text { mobile device } \\
\text { to read online. }\end{array}$ \\
\hline
\end{tabular}

The reality of exile was the backdrop of Ezekiel's prophecies (communication). He responded to this reality with a word that he claimed he received from $\mathrm{YHWH}$. This word he crafted into a powerful piece of communication that appealed, with the help of metaphors and images, to the imaginations of his audience. These imaginations of the future in the end seed the new possibilities that became their new reality. The question would be if Ezekiel's communication process could be helpful to leaders who find themselves in a new modern-day reality where they are struggling to lead.

Intradisciplinary and/or interdisciplinary implications: Prophetic criticism usually stays clear of practical issues like leadership, communication and change. This article attempts to construct a communication model from the prophet Ezekiel's communication that can help modern-day leaders to communicate amidst their reality. It aids in bridging the divide that exists between Practical Theology and Old Testament Biblical Studies.

\section{Introduction}

There is a shift in our society from our modernistic way of thinking to something new. Some academics are afraid to name this, but others are bold enough to refer to it as postmodern (Niemandt 2007:25-26; Sweet 1999:39) and others, not as bold, simply speak of an 'emergent' way of thinking or an 'in-between time' (Roxburgh 2010:28). Nevertheless, this paradigm of rapid change has become our reality.

The bottom line is that leaders (those leading churches) are struggling to chart these new waters and to lead with confidence and clarity. Weideman (2009) showed in a study, in which he conducted focus groups with church leaders from different provinces and different cultures in South Africa, that they feel almost helpless and overwhelmed to face the challenges that this huidige tydvak [current time frame] poses to them. Their experiences were summarised (Weideman 2009) as follows:

Die belewenis dat vinnige veranderings (oor 'n wye spektrum van die samelewing) groot druk op die interne en eksterne kapasiteit en hulpbronne van gemeenteleiers plaas. Baie van die gemeenteleiers beleef toenemende emosionele-uitputting en -nood as gevolg van hedendaagse eise wat gevoelens van moedeloosheid, eensaamheid en ook skuld by hulle veroorsaak. [The experience is that the rapid changes (over a broad spectrum of society) exert huge pressure on the internal and external capacity and resources of church leaders. Many of these leaders experience a growing sense of emotional burnout and emotional need, due to the current-day demands that leave them with feelings of discouragement, loneliness and guilt.] (bl. 108, [author's own translation])

This unfamiliar territory leaves many leaders looking at the methodology that guided them in the past, but as Roxburgh (2010:9) suggests, these methodologies (he calls them maps) are outdated and not able to navigate in this new reality. He also argues that maps do not disappear when our reality changes; they stay and continue to shape our habits (Roxburgh 2010:11). The challenge would be to become 'map-makers'. We should make new maps (Roxburgh 2010:16).

This reality of 'outdated maps' does have striking similarities with the Ezekiel story of exile. Ezekiel and his audience found themselves in new realities. Firstly, they were in exile with the hope of some rescue from Jerusalem ${ }^{1}$ and then their hopes were shattered when they received the news that the city had fallen. With this came the finality of the Babylonian exile. Old maps proved to be inadequate and the prophet had to - with the use of old maps (memories and images) create new maps that consisted of images of hope.

In the end all these realities boil down to the leader's ability to lead change and paint a picture of a preferable future. On this matter (we believe) Ezekiel's response is relevant. This article will show

1.The superscription of Ezekiel 1:1-3 place Ezekiel amongst the exiles who were part of the 597 BCE captives that were taken by Nebuchadnezzar (cf. Bowden 2010:2-3). 
how he communicated intentionally and how his process aided his audience. It will also show how his communicating process amidst his reality can be a helpful tool for leaders to communicate in a modern-day reality.

\section{Ezekiel's communication process}

In the Old Testament it was customary that people turned to their prophets in times of desperation. They needed words of explanation and comfort from their oracles. This is classically illustrated by the actions of the eager and desperate last king of Judah, Zedekiah, who secretly sent for the prophet Jeremiah 37:

Then King Zedekiah sent for him and had him brought to the palace, where he asked him privately, 'Is there any word from the Lord?' (v. 17)

The prophetic utterances of the prophets were in many ways the direction that the people and their leaders needed in difficult times. Ezekiel had several visits from the elders of his community (cf. Ezk 8:1;14:1;20:1). They came for his words his communication. These words and communications were claimed (by the prophet) to be the words of YHWH.

The process of communication was evident in the way Ezekiel communicated to his audience. We shall summarise it broadly and then embark on the detail of the process.

It appears that his communication firstly starts with the reality: the place they find themselves in. In this reality the prophet secondly receives a word that he claims has much higher authority. These are the words of YHWH. This happens in what Zimmerli (1982:99-110) calls a 'dabar moment'. Thirdly, out of this moment flows communication. This communication is poetic in nature and is filled with metaphors and images. It appears that there may be a time span between the 'dabar moment' and the actual communication. In this time the prophet crafts his communication, or as it shall be called, his 'poem'. Fourthly, this communication due to its rich imagery - latches onto the imaginations of the audience and helps them own, accept and understand, but also to dream. This dream in time becomes their new reality. This emphasises the idea that prophets do not necessarily predict the future but seed it with poetry and images.

\section{Step 1 (departure point): ${ }^{3}$ The reality of exile}

Most scholars agree that the first exile of $597 \mathrm{BCE}$ and final exile of 586 BCE were the reality of Ezekiel and his communication. Mein (2001:1) calls it a period of 'unparalleled crisis for the Jewish people, as successive Babylonian invasions left Judah devastated and Jerusalem in ruins'. To this reality the book of Ezekiel can almost be seen as a commentary that tries to explain the subsequent exile as a result of the people's moral failure.

2.All biblical quotes are from the $1983 \mathrm{New}$ International Version (NIV)

3.For the purpose of the process this first point is called a step, but is rather a point from where the communication departs: a birthplace for the communication that is to follow.
The book of Ezekiel itself puts the prophet amongst a first deportation of exiles that were taken by Nebuchadnezzar in 597 BCE (cf. Ezk 1:1-3). These exiles were taken from the elite of Jerusalem. The Zadokite priests, that Ezekiel was part of, were also taken with this group. Although this assumption has been challenged on many occasions ${ }^{4}$ it appears to hold firm as the most probable location for the prophet Ezekiel. Although Jews were found in three different locations during Ezekiel's tenure as prophet, his primary audience was the community of Jews in Babylon (cf. Block 1997:4-5). Without reconstructing the exilic conditions, one can easily imagine some of the realities that these people experienced:

- Ezekiel, at the age of 30, finds himself away from the temple where he so hoped to serve as a priest. The book starts by stating that this priest, Ezekiel, is 30. He was supposed to start serving as a priest at the age of 30, according to Numbers 4:30. Many of his own hopes and dreams were shattered. In this reality he receives the call to be a prophet (cf. Ezk 2:3-5).

- There was a sense of bewilderment and displacement that was part of their reality, because they had been removed from their homes, and their families were most likely divided and torn apart. ${ }^{6}$ They probably left behind family, social status and material possessions. They must have seen people killed during the siege and feared for their own lives (cf. Renz 1999:45).

- They also exchanged their homeland with its mountains and cooler climate for the flat and hot lowlands of Babylon (cf. Renz 1999:45).

- Certain things failed them: the monarchy and its leaders failed them and to a degree they felt that $\mathrm{YHWH}$ let them down as well. The latter would be something that the prophet would address in detail to show them that it was not YHWH who let them down, but their own covenant infidelity.

- Many things that gave them security, were stripped away from them. Their temple and the cultic practices that surrounded it gave them security; this was now far away and in danger of being destroyed.

- A new culture and new language were also part of their new reality. This made them feel even more dejected and lost.

4.It was Hölscher (in McKeating 1993:30-61) who in 1924 opened a new discussion on the authorship of Ezekiel that started some of the opposing views on the matter of Ezekiel's location. Up until then a consensus prevailed that the book showed of Ezekiel's location. Up until then a consensus prevailed that the book showed the mark of one single author. Holscher attributed only 147 of the 1273 verses in Ezekie to the original prophet. This critical handling of Ezekiel sparked a range of critical responses to the research on this book. Many of these were of the opinion that Ezekiel was either a pseudo author who used Ezekiel as a literary figure. Withou a doubt this posed questions about the prophet's location. Especially Torrey (in McKeating 1993:30-61) found Ezekiel's consistent focus on Jerusalem a problem to place the prophet in exile. These theories have however been rejected of late by scholars like Zimmerli (1979) and Greenberg (1983) (cf. McKeating 1993:30-61; Mein 2001:40-53).

5.'Since no proposal that dates "thirtieth year" from the exile of Jehoiachin is completely satisfying, the explanation of Origen long ago remains the most likely: the terminus a quo is the year of the prophet's own birth' (cf. Block 1997:82). Blenkinsopp (1990:16-17) is also a proponent of this view.

6.'There is some confusion about how many people were actually deported. The 10000 captives of 2 Kings $24: 14$ is contradicted by the 7000 men of valour and 1000 craftsmen and smiths of verse $16^{\prime}$ (cf. Mein 2001:55). Jeremiah 52:28 makes 1000 craftsmen and smiths of verse 16 (cf. Mein $2001: 55$ ). Jeremiah $52: 28$ makes agree with Robert Carroll (1986:869) 'such discrepancies are better not harmonized agree with Robert Carroll (1986:869) such discrepancies are better not harmonized
but accepted as evidence for the lack of definitive evidence available to the editors of the biblical stories'. 
Many things can probably be added to this list, but it is noteworthy to mention that there are those who argue that the conditions in exile were not all bad and that many of the Judeans quickly adapted to these new circumstances. ${ }^{7}$ Jeremiah 29:4-7 encouraged those who went into exile to engage in the culture and life of the foreign country. Nevertheless, to find oneself in a new country and culture against your will, taken there by your country's archenemy must have been a reality that was more disruptive than stable.

This above-mentioned reality forms the backdrop of Ezekiel's communication and therefore becomes his departure point.

What would the perspective be that this Old Testament book brings to our modern-day reality? The communicator who faces a new reality must be part of the reality. He needs to carry the reality like a burden. In some cases prophecies are referred to as 'oracles'. The word maśśā' is used in some prophecies and is usually translated with the word 'oracle'. 8 Verhoef (2006:19), when commenting on this word in Nahum 1:1 suggests that this word could also be translated with 'burden' and implies that the communicator of the oracle carries a heavy burden that needs to be communicated. Ezekiel uses this word once (24:25), but in a different context and with a different meaning but the idea is important: the reality must lay a burden on the communicator to which he must respond with a word, oracle and prophecy.

It is realities that create the vacuums in our modern-day society. In this vacuum uncertainty abounds and leadership is needed. There are two options as Sweet (1999) so rightly puts it in the sub-title of his book Soultsunami, Sink or Swim in New Millennium Culture. The communicator can hide away or deny the reality or he can embrace it like Ezekiel and begin the process of communication. In this process the next step would be to respond to the reality. In Ezekiel's case he responded with a word. This word was several prophecies that were filled with vivid images and graphic metaphors. His words accused, they explained, they refreshed the memory, they warned, they suggested and they hoped. In the end they started to create something new.

The next step in Ezekiel's communication process that was detected from reading the texts ${ }^{9}$ is what appears to be 'a word event'.

\section{Step 2: The 'word event'}

It was observed on several occasions when the texts were studied that most of Ezekiel's prophecies start with or have 7.Mein (2001:66-73) notes that these exiles were neither prisoners nor slaves and
were allowed some personal freedom to roam round and organise some sort of a community.

8.For a more detailed discussion of this concept, see Floyd (2002).

9.This article does not allow space to elaborate on the specific texts that were studied. However it is noteworthy to mention that they were studied in detail as part of a doctoral thesis that was presented in 2012 at Unisa by Serfontein (2012). He used doctoral thesis that was presented in 2012 at Unisa by Serfontein (2012). He used a selection of texts from Ezekiel due to the abundance of material in the prophetic book. He explains this selection (Serfontein 2012:11-15) and uses texts that are set prior to the fall of Jerusalem and the news thereof (Ezk 33:21) and of texts set post
the fall of Jerusalem. They were Ezekiel $6: 1-14 ; 7: 1-27 ; 16: 1-62 ; 34: 1-31 ; 36: 1-38 ;$ 37:15-28. These texts were studied (Serfontein 2012:78-130,140-181) and used to $37: 15-28$. These texts were studied (Serfontein 2012:78-130, 140-181) and used to
show how the prophet criticised and energised (according to Brueggemann's model show how the prophet criticised and energised (according to Brueggemann's model
of Prophetic Imagination) his audience with the images and metaphors in them. somewhere at the outset the following phrase 'the word of the Lord came to me'. A closer study of the Ezekiel prophecies revealed 32 occurrences of this phrase. Greenberg (1983:83) suggests more than 50 occurrences of this phrase. Although found in Jeremiah (six times) and in Zechariah (twice) this phrase is very distinctive to Ezekiel's communication. Zimmerli (1982:99-110) calls this the 'dābār (word) event' that is filled with the revelation of YHWH himself. This becomes throughout the book of Ezekiel like a rhythmic response. YHWH responds to the need of the moment with his word.

The question would be as to what lies behind this phrase? What happens at this moment? Does the prophet have some divine revelation or is this a so-called 'spiritual trance' that makes him experience messages from gods. Blenkinsopp (1983:41-42) deals with the issue of ecstasy when he discusses the social location of the prophet. To him prophets (biblical and other religions) do experience these trances to enhance their ability to receive a divine message. Certain stimulants like music, drums, self-laceration and drugs are used to obtain this state. This state would then indicate some sort of possession and therefore the possibility of divine intervention and divine messages being received. There are those who argue that biblical prophets receive this state by being possessed by the spirit of YHWH. Robson (2006:28-34) writes about this 'word event' and makes two observations. He firstly observes that the word event is closely linked to $\mathrm{YHWH}$ and shows how the phrase 'word of $\mathrm{YHWH}^{\prime}$ appears 225 times in the Old Testament and secondly he argues that in Ezekiel it is also linked with the 'spirit of YHWH'. Wilson (1980:145) as far back as the early 1980s was of the opinion, that there was a close correlation between spirit possession and this 'word' that the prophet received. This was the case in particularly the Ephraimite tradition (Wilson 1980:135-145). It is however noticeable that only Ezekiel connects his experiences of inspiration to the spirit of YHWH (Ezk 11:5), for the rest, spiritual ecstasy or inspiration by the spirit is seen as foolish and not appropriate. Mowinckel (2002:85) $)^{10}$ cites Hosea 9:7b: 'The prophet is a fool, the man of the spirit is mad', and shows that most of the spirit activities of the prophets were not seen in a good light. 'The older reforming prophets rejected the idea of inspiration in the form of possession by YHWH's spirit' (Mowinckel 2002:85). He argues that the inspiration of the prophets came when they withdrew from society ${ }^{11}$ and allowed the word of $\mathrm{YHWH}$ to come to them (Mowinckel 2002:88-89).

This opens the important discussion on the 'word event'. What then is the prophet's conception of YHWH's word? Mowinckel (2002) notes that:

A word in general did not mean to the ancient Israelite what we understand by a mere word. The word is active, and filled with the speaker's 'mental content'; his feelings, thoughts and will issue a word, which is also an act. YHWH's word is also an action. It is a real active force, a potency that YWHH can 'send forth' and that can 'descend upon' people with devastating effect (Isa 9:7). (p. 90)

10.1 am aware that Sigmund Mowinckel passed away a long time ago, but the publication I studied was published in 2002, The Spirit and the Word, and was edited by K.C. Hansen in honour of Mowinckel.

11.I I did not sit in the company of merry makers, nor did I rejoice; I sat alone, because your hand was upon me, for you had filled me with indignation', Jeremiah 15:17. 
The fact of the matter is that Ezekiel frequently uses the phrase 'and the word of the Lord came to me'. Maybe it can be argued that the prophet just uses this phrase to give more authority to his own words or the words that he perceived may have come from YHWH. Robson (2006:29) agrees with this. To him this is also a 'call to attention formula' that the prophet employs to authenticate his communication. The Septuagint (LXX) translate the Hebrew word dāba $r$ with two different Greek words: 'logos' and 'rhema'. In the historical books of the Old Testament the translators preferred 'logos' but in the prophetic books 'rhema' dominates almost eightfold. The word 'rhema' is better understood as 'utterance'. If 'utterance' is more often implied in the prophetic books, it opens the discussion even further. Does the prophet receive a direct and audible utterance from $\mathrm{YHWH}$ ? On two occasions (Ezk 14:1; 20:1) the elders are present during this 'word event' that Ezekiel experiences. They sit in front of Ezekiel when it happens, but the prophet still needs to communicate it to them. To us this indicates that the 'word event' happens privately. If it happened publicly the need for prophetic utterance would not be needed. Robson (2006:34) and Ellens (2000:1386) agree on this. Ellens (2000:1386) does make the observation that many times this word is 'metaphoric' in nature. This was evident in the communication of Ezekiel that we observed. The prophet received his messages in the form of metaphors that he communicated along with some well-known messenger, recognition and word formulas.

Meier (2009:53-54) tries to understand the manner of the revelation of this 'word' that comes to the prophet. He feels, the fact that there is a 'lack of interest' in most prophetic literature to define this, points to the fact that we are indeed dealing with a tradition where 'congenial dialogue' between God and the prophet was assumed. Important for this article is the fact that Meier (2009:59) notes that a change happens in the book of Ezekiel. The revelation of YHWH is much more theophanic in nature. The dialogue also becomes less evident and the prophet on many occasions seems to be on the receiving end of a word, without being able to respond to YHWH. The prophet's response must therefore be his communication with his audience.

Brueggemann (2007:9-16) offers three modes of explanation for the word that is 'other than one's own':

- It comes from a good and strong sense of calling. The prophet is thoroughly aware of the fact that there is a divine 'impingement ${ }^{\prime \prime 2}$ on their lives. Isaiah, Jeremiah and Ezekiel all allow for an elaborate narrative of their calling and how YHWH promised to be with them in everything they will do. This would also include communicating. The prophet's words would be YHWH's words as well.

- There is the claim that the prophets had access to some form of divine counsel (cf. Jr 23:18, 22). In other words they somehow have this experience of standing amongst the gods and receive from them their words.Finally, the messenger formula, 'thus saith the Lord' is more evidence that the prophet claims to receive words that are other than his own.

12.The word 'impingement' is used by Brueggemann (2007).
For us this 'word event' can be a little bit of both: the prophet can receive a dream, vision or impingement from $\mathrm{YHWH}$, but he also listens with his own ears and understanding. He speaks from his own knowledge of how YHWH would respond as well. This is illustrated in the introductory verses of the book of Jeremiah:

The words of Jeremiah son of Hilkiah, one of the priests at Anathoth in the territory of Benjamin. The word of the Lord came to him in the thirteenth year of the reign of Josiah son of Amon king of Judah. (Jr 1:1-2)

Brueggemann (2007:14-15) makes a valid argument for the fact that most prophetic utterances are deeply grounded in tradition and in particular the tradition of Deuteronomy. Mowinckel (2002:94) also makes this point to a degree when he argues that many of the prophets' convictions concerning the word of YHWH came from them 'knowing' YHWH's nature and mode of actions that are governed by moral norms; in most cases revolving around the covenant agreements.

In the light of this one can argue that Ezekiel's experience of this 'word event' was on the one hand an experience he had with YHWH: this could be a realisation of something or a sense of inspiration. On the other hand this 'word event' was also a realisation of truth that was in him due to his knowledge of YHWH. The words of the prophet and the 'word of the Lord' are combined to create a response to a specific reality. Ezekiel, more than any other prophet, authenticates his words by connecting them to the words of YHWH. It became obvious when the selected texts of Ezekiel were studied that a 'word event' preceded his communication (cf. Ezk 6:1; 7:1; $16: 1 ; 34: 1 ; 36: 16 ; 37: 15)$.

How would the modern-day communicator experience this 'word event'? In some Christian traditions it is taken as a given that inspiration from God is part of the communicating process. Every time a pastor, priest or Christian communicator approaches a podium it is assumed by the audience that what he or she has got to say will be words other than his or her own. Brueggemann (2007:13) tries to explain the phrase 'words other than one's own' by acknowledging that 'some direct, personal intimate impingement of God' on the preacher is a prerequisite for effective preaching. He notes however that a correlation exists between what this inspiration is and the preacher's own traditions (mainly rooted in the text of the Bible) take on reality.

We would suggest that a few possible actions, as seen from the text of Ezekiel and Old Testament prophetic tradition, might bring about this 'word event' that is so crucial in communicating:

- Firstly, a good take on reality is needed to be in a space where this 'word' can be received. If the communicator is out of touch with the realities his audience is facing, his communication will be irrelevant. 
- Secondly, it appears that solitude plays a part in receiving this word. ${ }^{13}$ It appears that the prophets either withdrew ${ }^{14}$ themselves for a time or moved themselves to a place where they could be comfortable to receive 'the word' from YHWH (cf. 1 Ki 19:12-13; Jr 15:17b; Hab 2:1; Ezk 9:8). In the modern context this would mean to quieten the many voices that form part of our everyday lives. Some traditions would suggest prayer and others contemplation; nevertheless in these moments a communicator might find the inspiration or creation of an idea or thought that may be his own, or might be 'other than his own'. In business leadership circles a lot is made of so-called 'reflective practices' that a leader must incorporate in his life to lead effectively.

- Finally, a good knowledge of God and the biblical traditions may also aid this moment. It was shown earlier that the prophets drew from their knowledge of $\mathrm{YHWH}$ and from the traditions they stood in. A good modern-day communicator must then firstly be rooted in the biblical narratives. ${ }^{15} \mathrm{He}$ must have respect and knowledge for the biblical text and be able to move to it from the modernday reality and from it to the reality. Secondly he must have some relational knowledge of God. This may be the same type of interpretation that Goldingay (2011:43) calls 'believing criticism'. ${ }^{16}$ This type of interpretation of the text according to him (Goldingay 2011:50) 'enthuse(s) over the way the Spirit inspires imaginative leaps in the use of scripture that may give words significance'. This may create a point of dispute because many claim that this is not possible, but it is claimed in most Christian traditions to be more or less possible.

This 'word' or inspirational moment is the beginning of the prophet's response to the reality. After this has happened the prophet enters the next step. He creates his communication material or as laid out in the steps: he creates a poem.

\section{Step 3: Creating and communicating the poem}

A next step in the communication of Ezekiel is surely the delivery of this 'word' that he received. We would like to argue that this communication is twofold in nature and that before the prophet goes public with his message and communicates it, he takes time to create his message or as it shall be called: his poem. We are not sure when or how this happens but it is evident that the choice of imagery and metaphors was not accidental, but chosen for a specific

13.Prophets in general operated much more peripherally than other institutions or traditions like for instance scribes and priests. This allowed them to criticise the economic and social policy of the monarchy independently as agents of YHWH, but also supplied them with ample solitude (cf. Van Heerden 1991:207-208).

14.This is also seen in the life of Jesus in the New Testament who came as a prophet and claimed to speak 'words' he received from God (cf. Mk 1:12-13, 35; 6:31, 46, $9: 2 ; 14: 32)$.

15.Goldingay (2011:258) notes that the prophets used narratives to make theological statements about God. The prophets built their communication on these narratives.

16.Believing criticism believes that everything in the Bible is indeed true, but that not everything that the church and scholars teach about it is always true. Goldingay (2011:46) notes that none of the questions that were asked in the 19th century have been solved and that in order for interpretation to stay relevant it needs to have been solved and that in order for interpretation to stay relevant it needs to
focus on what can be known and applied from the text rather than focusing on 'questions that run into the sand'. reason to communicate something. It is hard to believe that this communication was spontaneous, 'spur of the moment' responses or that they were an autonomic response to some divine inspiration. With autonomic response we refer to the belief that Bible writers wrote or spoke whilst they were totally under the influence of some divine power; a belief that is held in many conservative Christian circles. ${ }^{17}$

The interaction with the texts of Ezekiel confirmed this: apart from the well-known fact that many prophecies are in the form of poetry, they are also filled with images, metaphors and sign acts. All these are part and parcel of poetic literature. If one thinks of the powerful metaphor of Jerusalem - as an orphan turned queen turned harlot - in Ezekiel 16, one cannot but conclude that the prophet had to take time to prepare this oracle. He had to think about how it would flow and how he would best communicate the 'word' that he felt was needed as a response to his audience's reality at that moment. On the other hand, if you have to speak life into the hopeless exilic community, what better way than to speak of a 'valley of dry bones' that at one stage confesses their own hopelessness (Ezk 37:1-14)? What better way than to bring them together and to life, due to the spirit that moves through them? For these poetic forms of communication to take place the prophet must take time to prepare the poem and indeed be a poet of some sort.

This statement probably needs some elaboration. Robert Carroll (1996:25-31) in response to a paper by Auld (1996) made the following statement: 'the individuals traditionally known as prophets should not be regarded as prophets but require a different description. They were certainly poets, probably intellectuals, and possibly ideologues' (Auld 1996:25). He observes that the usually open and hostile attack of the prophets on the social institutions is more likened to poets than prophets. We find throughout history that it is the artists in general who question and challenge the social structures. Carroll (1996:27-28) holds that the original prophets were poets, but that the process of redaction transformed them into conventional prophets. In support of his notion he quotes Max Weber who called the prophets 'demagogues and pamphleteers' who, through their poems suggested the need for social change.

Ezekiel the prophet or poet (as presented to us in the book of Ezekiel) then communicates his poem, sometimes in a poetic structure and manner, (cf. Ezk 7:1-27; 17:1-9; 19:1-14; $21: 8-17,28-32 ; 27: 1-36 ; 28: 11-19 ; 29: 3-7 ; 30: 1-6 ; 31: 1-9$; 32:1-32), on other occasions with the use of vivid imagery as suggested in a previous paragraph or with the help of sign acts (cf. Ezk 3:22-27; 24:25-27; 33:21-22; chs. 4-5; 6:11-12; $12: 1-16,17-20 ; 21: 11-29 ; 24: 15-24 ; 37: 15-28)$ that help to illustrate his message. His communication then challenges

17.We are aware of the debate in Prophetic Studies that deals with the question of a prophet as 'social phenomenon or a literary one' (cf. Nissinen 2009:106). They
argue that in the past the prophet was too easily seen as the writer of the material as well (cf. Wessels 2009:216-217). Ben Zvi (2009) is a proponent of the view that many literatures originated in the 'second temple period' at the hands of 'literati'. many literatures originated in the 'second temple period' at the hands of 'literati'.
These literati would then be far removed from the original producer of the oracles, but also clothed with ideology (Ben Zvi 2009:24-25) 
TABLE 1: Summary of studied texts.

\begin{tabular}{|c|c|c|c|}
\hline Ezekiel & Metaphor or image & Words or phrases & Imagination appeal \\
\hline \multirow[t]{9}{*}{ Ezekiel 6, 7 and $16 \dagger$} & Sword & - & YHWH has now turned against them \\
\hline & Mountains and land & - & Totality \\
\hline & Scattering of flock & - & No leadership and no protection \\
\hline & YHWH turning his face away & - & $\begin{array}{l}\text { Disappointment of YHWH as betrayed } \\
\text { partner and seriousness of the situation }\end{array}$ \\
\hline & Orphan who became queen; who became a harlot & - & $\begin{array}{l}\text { The actions of affection by YHWH are } \\
\text { thrown back into his face. Their deeds are } \\
\text { the ultimate betrayal }\end{array}$ \\
\hline & - & Detestable practices & YHWH's actions were justified \\
\hline & - & Covenant & $\begin{array}{l}\text { The infidelity is played against YHWH'S } \\
\text { loyalty towards the covenant }\end{array}$ \\
\hline & - & End has come & Finality \\
\hline & - & They will know that I am the Lord & $\begin{array}{l}\text { The imagination has gone full circle and a } \\
\text { realisation of their reality and the part they } \\
\text { played in creating it }\end{array}$ \\
\hline \multirow[t]{7}{*}{ Ezekiel 34,36 and $37 \ddagger$} & YHWH as their shepherd & - & $\begin{array}{l}\text { He juxtaposes the leaders' neglect against } \\
\text { YHWH's care and protection }\end{array}$ \\
\hline & Covenant & - & $\begin{array}{l}\text { A new covenant where they will act as } \\
\text { faithful covenant partners and have a } \\
\text { faithful servant (like David) ruling over } \\
\text { them }\end{array}$ \\
\hline & Land and mountains & - & $\begin{array}{l}\text { Where it was previously used to proclaim } \\
\text { the judgement in its totality it is now used } \\
\text { to show the salvation in its totality }\end{array}$ \\
\hline & Dry bones that become an army & - & $\begin{array}{l}\text { They are depleted of hope and expectation } \\
\text { and truly defeated but they come together } \\
\text { as an army with expectation }\end{array}$ \\
\hline & Graves open & - & $\begin{array}{l}\text { Their dead and dried up hopes will come } \\
\text { to life }\end{array}$ \\
\hline & The two sticks & - & Two nations becoming one \\
\hline & - & I will be their God, and they will be my people & $\begin{array}{l}\text { Again the imagination's circle is completed } \\
\text { and their expectations are at their fullest }\end{array}$ \\
\hline
\end{tabular}

$\dagger$, For a detailed discussion see paragraphs 4.5 and 6.4.1. in Serfontein, J.L., 2012, 'An Old Testament Perspective on Imagining in a Changing Society: Ezekiel as Case Study', Doctoral thesis, Department of Old Testament and ANE studies, Unisa.

$\$$, For a detailed discussion of this see paragraphs 5.5 and 6.4.2. in Serfontein, J.L., 2012, 'An Old Testament Perspective on Imagining in a Changing Society: Ezekiel as Case Study', Doctoral thesis, Department of Old Testament and ANE studies, Unisa.

the reality or as Brueggemann (1989:3) articulates, 'poets that speak against a prose world' and with 'prose world' he refers to the organised and settled reality that the audience find themselves in. It becomes daring speech that is dramatic and alternative - alternative to the current reality - and assaults the imagination.

Studying some of the texts in Ezekiel, one can see that the prophet showed the exiles the impending doom due to their own deeds (Ezk 6, 7 \& 16), but also the possibility of salvation (Ezk 34, 36 \& 37) on account of YHWH's goodness.

Ezekiel's process suggests that after the prophet received his message ('word event') a next step was to sit down and take time to best prepare a piece of communication (communiqué) that would get the audience's attention and also latch onto their imaginations. When this communication happens it is filled with poetry, metaphors, images and sign acts. Psychologists use imagination to help their patients understand their stories and to create new stories on their way to recovery and Ezekiel did the same with the use of his prophetic imagination. This brings interesting perspectives to the modern-day communicator:

- It firstly suggests preparation. If the communicator (or leader, or preacher) claims to have received a 'word other than his or her own', time must be set aside to prepare a communiqué that will engage the audience.

- Secondly, this 'piece of communication' could be called anything from a 'talk' to the more traditional sermon, but it must be a response to the reality (Step 1 of Ezekiel's process) and it must be a 'word' that responds to this reality (Step 2 of the process).

- Thirdly, rhetorical devices like poetry, images, metaphors and sign acts must be included to help the audience remember and understand the communication. ${ }^{18}$

John Ortberg, a modern-day communicator, illustrated this when he used the famous Creation of Adam fresco by Michelangelo to illustrate God's actions of love toward mankind and mankind's reluctance to respond. In the painting God appears to be determined to reach out and be with the person he created whilst Adam only has to lift his finger to touch his creator (cf. Ortberg 2005:13-14). This image helps to communicate a truth. Over the years communicators have used jars filled with stones, water bottles, poems, songs and recently clips from movies, to help them communicate and turn their piece of communication into a relevant modernday poem. This step requires time and creativity but can be helpful to an audience that find themselves in a fast-changing and highly challenging environment.

\section{Step 4: Appealing to the imagination to see the new possibilities}

Table 1, that is a summary of the texts that were studied, shows how Ezekiel uses images and metaphors for a

18.Sandra Levy (2008:50-65) advocates the fact that an audience can easily meet God and his revelation of a specific reality through poetry. She then shows through poems by R.S. Tho uses themes aith journey and interaction with God. This would mean that the communicator can use the many poems (even the visual arts as she also suggests) that are at our disposal as a tool to communicate. 
specific imaginary appeal. He uses two kinds of prophetic imagination: the first type is the so-called 'prophetic criticising' that forms part of the chapters studied prior to the fall of Jerusalem (Ezk 6, 7 \& 16) and the other part is called 'prophetic energizing' and is taken from his prophecies after the fall of Jerusalem (Ezk 34, 36 \& 37). We shall therefore not discuss it in full here, but only include this summary to aid the dialogue that will follow.

Ezekiel uses his words, metaphors and images to appeal to his audience's imagination to help them in the first instance understand their reality and secondly help them to embrace future possibilities.

In 2012 Walter Brueggemann set out once again to revisit the subject of 'prophetic imagination' and tried to show the credible connection that can be seen between the prophetic utterances of the Old Testament prophets and the practice of 'prophetic preaching'. He (Brueggemann 2012) proposes that:

Prophetic proclamation is an attempt to imagine the world as though YHWH were a real character and an effective agent in the world ... The key term in my thesis is 'imagine', that is, to utter, entertain, describe, and construe a world other than the one that manifests in front to us ... Thus prophetic imagination is one that contradicts the taken-for-granted world around us. (p. 2)

Communicating becomes the staging of two narratives against each other: the reality and the possibility. In the end YHWH's account would be more normative and one that must be imagined (cf. Brueggemann 2012:2-4). On the issue of narratives Eslinger (1995:141-152) shows how important narratives are in creating images for the imagination. He notes (Eslinger 1995:144-145) that images allow us to focus on a particular aspect of what we experience and that they can serve to provide new insights. One only has to refer back to the powerful narrative of Ezekiel 16 of the orphan who becomes a queen and then a harlot, or the narrative of the valley of the dry bones to understand that this was true in Ezekiel's case. With a narrative you open up some human truth that lies beneath, even beyond, the everyday norm. You skilfully re-view and re-order the world around you with this story. Levy (2008:52) warns that 'mental gaps' can be 'created by the artist pushing metaphor or symbol into new realms of meaning'. This does not have to be a problem because application is always a personal event and the so-called 'mental gap' needs to be filled with one's own interpretation, thus making the metaphor more personal and more powerful.

What perspective would this step in Ezekiel's communication bring to the modern-day communicator? It would be that we must communicate with stories and metaphors that dare to imagine something different, meaningful and significant. Something different to the current reality, something meaningful to our knowledge of God and significant to our needs. It would also suggest that some of our communication must be 'open-ended' allowing for personal application and imagining. It must allow the audience to create their own map through their reality with the help of familiar metaphors.

\section{Conclusion}

This article showed that a process can be detected from the way in which Ezekiel communicated amidst his reality. This process started in the reality of exile in Babylon. In this reality the prophet receives a 'word' that he skilfully communicates in the form of a poem that intends to appeal to his audience's imagination. The images that the audience are suggested to imagine speak of new possibilities. These new possibilities are in actual fact at first 'impossibilities'. Modern-day communicators and leaders can therefore turn to the many Old Testament narratives and, as is shown in this article, to Ezekiel to find a process of communicating and the evidence of these 'possibilities' when we confront our modern-day reality. The prophet with his daring utterances believed that YHWH would work the impossible yet again and the communicator can do the same, but with more boldness due to the many more traditions available to him or her. These daring utterances of the communicator help the audience to imagine despite the situation in which they find themselves. This imagination is then the seeded beginnings of a new reality. By this communication the prophet, poet, or communicator creates the future rather than predicting it.

\section{Acknowledgements Competing interests}

The authors declare that they have no financial or personal relationship(s) that may have inappropriately influenced them in writing this article.

\section{Authors' contributions}

J.S. (University of South Africa) was the author and W.J.W. (University of South Africa) acted as co-author.

\section{References}

Auld, A.G., 1996, 'Prophets through the looking glass: Between the writings and Moses', in P.R Davies (ed.), The Prophets, pp. 22-42, Sheffield Academic Press, Sheffield.

Ben Zvi, E., 2009, 'Towards an integrative study of authoritative books', in D.V. Edelmann \& E. Ben Zvi (eds.), The production of prophecy: Constructing prophecy and prophets in Yehud, pp. 15-28, Equinox, London.

Blenkinsopp, J., 1983, A history of prophecy in Ancient Israel, Society for Promoting Christian Knowledge, London.

Blenkinsopp, J., 1990, Ezekiel, John Knox, Louisville.

Block, D.I., 1997, 'The Book of Ezekiel (Chapters 1-24)', in R.K. Harrison \& R.L. Hubbard Jnr (eds.), The New International Commentary on the Old Testament, n.p., Eerdmans, Grand Rapids.

Bowden, N.R., 2010, Ezekiel, Abingdon, Nashville.

Brueggemann, W., [1978] 2001, Prophetic imagination, Fortress, Philadelphia.

Brueggemann, W., 1989, Finally comes the poet, Fortress, Minneapolis.

Brueggemann, W., 2007, The word militant, Fortress, Minneapolis.

Brueggemann, W., 2012, The Practice of Prophetic Imagination, Fortress, Minneapolis.

Carroll, R.P., 1986, Jeremiah: A commentary, Old Testament Library, London.

Carroll, R.P., 1996, 'Poets not prophets: A response to "Prophets through the looking glass"', in P.R. Davies (ed.), The Prophets: A Sheffield Reader, pp. 43-49, Sheffield Academic Press, Sheffield.

Ellens, J.H., 2000, 'Word', in D.N. Freedman (ed.), Dictionary of the Bible, pp. 1386 1387, Eerdmans, Grand Rapids. 
Eslinger, R.L., 1995, Narrative and imagination: Preaching the world that shapes us, Fortress, Minneapolis.

Floyd, M.H., 2002, 'The maśśā' as a type of prophetic book', Journal of Biblical Literature 121(3), 401-422.

Goldingay, J., 2011, Key questions about biblical interpretation, Barker Academic, Grand Rapids.

Greenberg, M., 1983, s.v. 'Ezekiel, 1-20', The Anchor Bible, Doubleday, Garden City, NY., n.p.

Levy, S.M., 2008, Imagination and the journey of faith, Eerdmans, Grand Rapids.

McKeating, H., 1993, Ezekiel, JSOT, Sheffield.

Meier, S.A., 2009, Themes and Transformations in Old Testament Prophecy, InterVarsity Press, Downers Grove, IL.

Mein, A., 2001, Ezekiel and the Ethics of Exile, University Press, Oxford.

Mowinckel, S., 2002, The Spirit and the Word, K.C. Hanson (ed.), Fortress Press, Minneapolis.

Niemandt, N., 2007, Nuwe Drome vir Nuwe Werklikhede, Lux Verbi.BM, Wellington.

Nissinen, M., 2009, 'The historical dilemma of biblical prophetic studies', in H.M Bastad \& G. Kratz (eds.), Prophecy in the Book of Jeremiah, pp. 103-120, Walter de Gruyter, New York.

Ortberg, J., 2005, God is closer than you think, Zondervan, Grand Rapids.

Renz, T., 1999, The Rhetorical Function of the Book of Ezekiel, Brill, Leiden.
Robson, J., 2006, Word and Spirit in Ezekiel, T\&T Clark International, New York.

Roxburgh, A.J., 2010, Missional Map-Making, Jossey Bass, San Francisco.

Serfontein, J.L., 2012, 'An Old Testament Perspective on Imagining in a Changing Society: Ezekiel as Case Study', Doctoral thesis, Department of Old Testament and ANE studies, Unisa.

Sweet, L.I., 1999, Soultsunami: Sink or swim in new millennium culture, Zondervan, Grand Rapids.

Van Heerden, W., 1991, 'Prophets and Prophiteers: Prophetic perspectives on wealth and poverty', in H.L. Bosman, I.G.P. Gous \& I.J.J. Spangenberg (eds.), Plutocrats and Paupers: Wealth and Poverty in the Old Testament, pp. 206-227, Van Schaik, Pretoria.

Verhoef, P.A., 2006, Die boek Nahum, Lux Verbi. BM, Wellington.

Weideman, J.H., 2009, 'Strategieë om gemeenteleiers te ondersteun om die eise van die huidige tydvak in Suid-Afrika in hulle bedieninge aan te spreek: 'n Fenomenologiese ondersoek', Doctoral thesis, Department of Theology, University of Johannesburg.

Wessels, W.J., 2009, 'Tendense in Profetenavorsing', Old Testament Essays 22(1), 205-227.

Wilson, R.R., 1980, Prophecy and Society in Ancient Israel, Fortress Press, Philadelphia. Zimmerli, W., 1979, Ezekiel 1, Fortress Press, Philadelphia.

Zimmerli, W., 1982, I am Yahweh, John Knox, Atlanta. 